\title{
Design and Application of Marionette Tangram: An Educational Teaching Media for Mathematics and Social Science Learning Process in Elementary Schools
}

\author{
Eka Zuliana $^{1,{ }^{*},}$ Ika Oktavianti ${ }^{1}$, Yuni Ratnasari ${ }^{1}$, Henry Suryo Bintoro $^{2}$ \\ ${ }^{1}$ Department of Elementary Education, Faculty of Education, Muria Kudus University, Indonesia \\ ${ }^{2}$ Department of Mathematics Education, Faculty of Education, Muria Kudus University, Indonesia
}

Received December 17, 2019; Revised January 23, 2020; Accepted February 18, 2020

Copyright $\odot 2020$ by authors, all rights reserved. Authors agree that this article remains permanently open access under the terms of the Creative Commons Attribution License 4.0 International License

\begin{abstract}
Teaching media is one of the important things in the learning process. It can stimulate and motivate elementary school students to learn the materials in the learning process. Marionette Tangram is an educational teaching media for elementary school students which can be used in geometry in mathematics and history subjects. This research was a developmental research using the 4D (four D) model of Thiagarajan. This paper summarizes how to define, design, develop, disseminate and apply the Marionette Tangram. Needs analysis of the media was conducted in the "define" phase. The prototype of the educational teaching media was created in the "design" phase. The experiment was carried out in the "develop" phase. In the dissemination phase, information related to the instructions on how to use the media was given to the teachers in many schools. The last phase was to register the copyright of Marionette Tangram media at the Ministry of Law and Human Rights of the Republic of Indonesia. The results of this research show that Marionette Tangram is an innovative educational teaching media because it is formed from cultural values and can be used in the learning process as a teaching aid for mathematics and history subjects. Furthermore, it can be categorized into valid criteria; and the instructional application is effective.
\end{abstract}

Keywords Marrionette Tangram, Educational Teaching Media, Elementary School

\section{Introduction}

Elementary school curriculum in Indonesia is using thematic approach. Thematic approach is a learning approach that integrates various competencies from various subjects into a certain theme ([1], [2], [3]). This learning approach has an actual theme that is close to the students and exists in their daily life. This theme becomes a unifying material that is diverse from various subjects. Implementation of integrated thematic learning model in the 2013 curriculum was strengthened by the use of scientific approach. In the learning activities based on scientific approach, students are required to think scientifically to construct a concept or principle. Stages of learning activities using the scientific approach include observing, asking questions, trying/ gathering information, reasoning/ associating, and communicating [4]. Elementary school students who are at the concrete level ([5], [6]) need concrete objects that can be held, felt and manipulated in order to find concepts. Therefore, appropriate teaching methods need to be designed relevant to their cognitive level.

Educational teaching media are tools in the learning process to connect the materials ([7], [8]). Media is something that can make the students motivated in the learning process [9]. Marionette Tangram is one media from Tangram's puppet which is controlled using wires. This media supports the thematic learning process especially for mathematics and social sciences that can build the students' character education.

\section{Materials and Methods}

This research was a developmental research using the 4D model of Thiagarajan (Define, Design, Develop and Dissemination) [10]. The instruments of the research consist of: (1) Marionette Tangram validation questionnaire by the experts in content, (2) Marionette Tangram validation questionnaire by the experts in media, (3) Marionette Tangram validation questionnaire by 
teachers, and (4) student questionnaire. Data analysis was conducted qualitatively and quantitatively using Likert Scale ([11], [12]). Validation score consists of four categories: (4) valid, (3) fairly valid, (2) less valid and (1) not valid. Score of the data is converted into percentage [13]. Table 1 below presents the validity criteria that are converted into percentage.

Table 1. Validity Criteria

\begin{tabular}{|c|c|c|}
\hline Percentage & Validity Criteria & Description \\
\hline $81-100$ & Strongly Valid & Not revised \\
\hline $61-80$ & Valid & Not revised \\
\hline $41-60$ & Fairly valid & Revised \\
\hline $21-40$ & Less valid & Revised \\
\hline $0-20$ & Not valid & Revised \\
\hline
\end{tabular}

The design of Marionette Tangram development is presented in Figure 1 below.

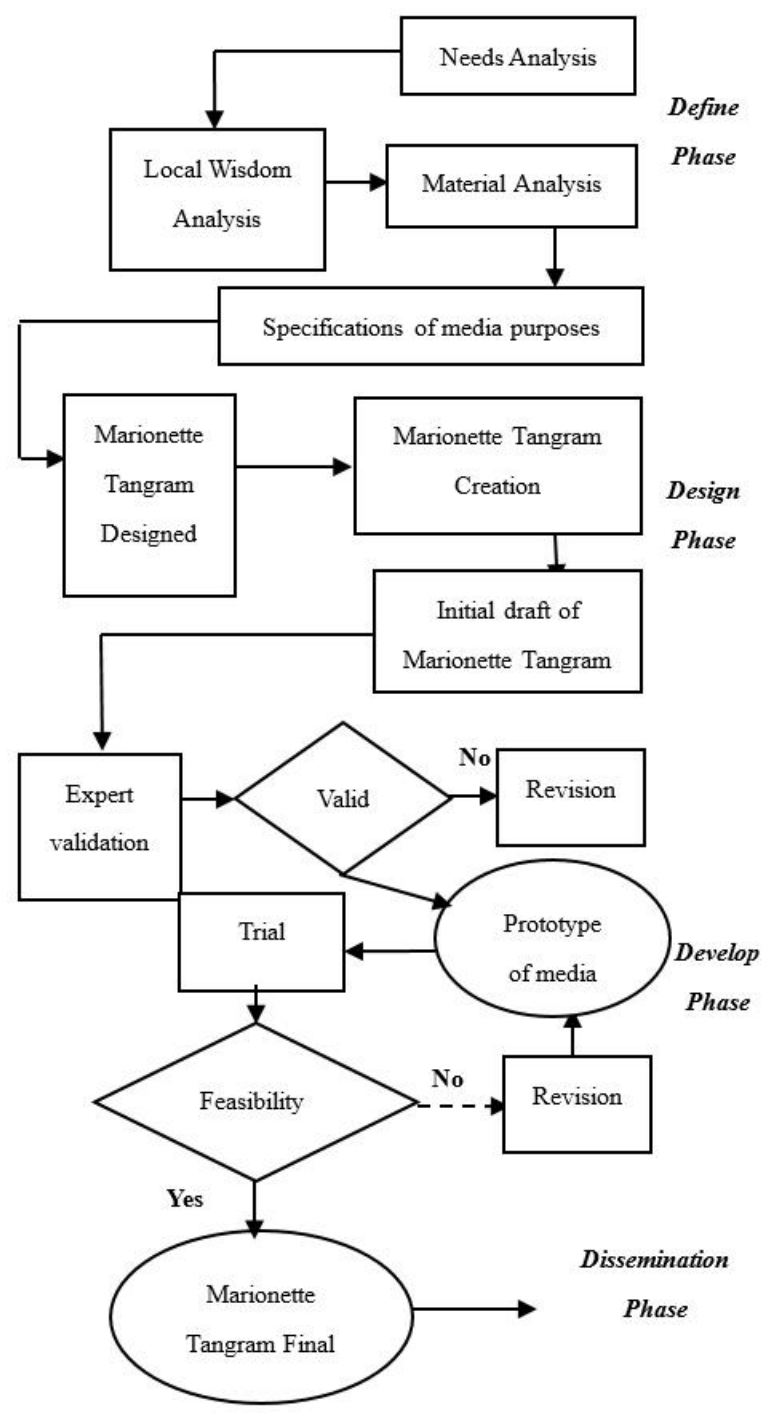

Figure 1. Marionette Tangram Development

\section{Results and Discussion}

\subsection{Define Phase}

In this phase, a preliminary study was carried out in the form of a literature study and needs analysis of the media.

\subsubsection{Literature Study}

The literature study is about learning media, material content in thematic learning process especially mathematics (the characteristic of plane), social sciences (history) and local wisdom.

\subsubsection{Needs Analysis of Media}

The activities were performed using requirement analysis regarding whether the learning media was needed to be developed or not. Some findings in this phase included student response during the learning process. The data of student questionnaire results can be seen in table 2 .

Table 2 indicates the following learning activities: 1) thematic learning process was conducted using speech method, 2) thematic learning process was not supported by an appropriate and interesting learning media, 3) the learning media was still limited to some materials in some lessons, 4) the learning media based on local wisdom was needed to bring students closer to their local wisdom, 5) students agreed to use learning media in the learning process, and 6) students were not familiar with learning media based on local wisdom like Marionette Tangram.

Table 2. Student Questionnaire on Preliminary Study

\begin{tabular}{|c|l|c|}
\hline No & Indicators & Percentage \\
\hline 1 & $\begin{array}{l}\text { Thematic learning process using speech } \\
\text { method }\end{array}$ & $90 \%$ \\
\hline 2 & $\begin{array}{l}\text { Thematic learning process should use } \\
\text { innovative learning method in addition to } \\
\text { speech and book }\end{array}$ & $85 \%$ \\
\hline 3 & $\begin{array}{l}\text { Thematic learning process using innovative } \\
\text { and interesting educational teaching media }\end{array}$ & $35 \%$ \\
\hline 4 & $\begin{array}{l}\text { Students agree to use learning media in the } \\
\text { learning process }\end{array}$ & $88 \%$ \\
\hline 5 & $\begin{array}{l}\text { Students are familiar and interested to the } \\
\text { local wisdom }\end{array}$ & $32 \%$ \\
\hline 6 & $\begin{array}{l}\text { Students have used educational teaching } \\
\text { media based on local wisdom }\end{array}$ & $0 \%$ \\
\hline
\end{tabular}

Table 2 shows that educational teaching media is necessary to improve the quality of the thematic learning process. One of the important things in thematic learning process is to establish the learning tools and media in addition to the learning approach, discovery of the concept and student interaction [14]. The media also improves student motivation and their participation in the class discussion [15] 


\subsection{Design Phase}

In the define phase, the appropriate teaching media was designed. Local wisdom related to the theme was the basis for making the media. Marionette Tangram was designed from Tangram puppets. Marionette is a puppet with wires that is controlled from above [16], while Tangram is a truncated puzzle which is divided into 7 geometrical shapes called tans [17]. Figure 2 below describes the design.

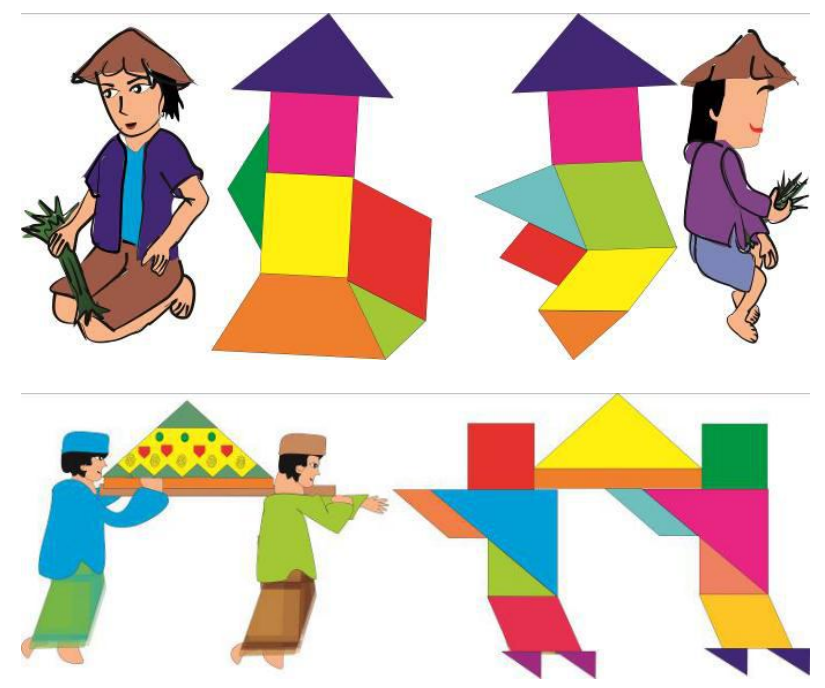

Figure 2. The design of Marionette Tangram

The design described the activities in Bulusan story (a local wisdom from Kudus, Central Java, Indonesia). Bulusan story is related to the cultural diversity theme in the thematic learning process for the fourth-grade students in elementary school. The following steps show the instructions to use the media.

1. The teacher motivates students and encourages students' curiosity by using media in learning.

2. The teacher divides students into groups and each group is asked to share their initial knowledge related to cultural traditions that exist in the environment around the students. "Try to identify what cultural traditions exist in the environment around us!" (In this case was Kudus area). The students' answers include the tradition of 'dandangan', 'sewu kupat', and 'Bulusan'.

3. The teacher conveys that on this occasion the 'Bulusan' tradition will be studied

4. Students are asked to share their initial knowledge related to the 'Bulusan' tradition. "Students, you mentioned earlier that one of our cultural traditions is the Bulusan tradition. Tell me about your knowledge related to this tradition. (students will tell their initial knowledge related to the tradition).

5. The teacher tells the story by using Marionette Tangram as the Bulusan's educational media.

6. Students are asked to retell the tradition and demonstrate it using the media.
7. Students are asked to try to identify the noble values of history, religious and character contained in the story and the cultural traditions.

8. Teaching geometry using Marionette Tangram. Students are asked to identify some of the plane shapes that exist in the media such as square, rectangle, triangle, rhombus, parallelogram and trapezoid. "Look at the back of the Marionette Tangram in Bulusan, What do you find?" (Combining several plane figures/two dimensional figure). "Try to mention any plane shapes that build the media" (The conditional answer corresponds to the plane figure on the back of the characters).

9. Students are asked to identify the characteristics of the plane shapes that form the Marionette Tangram in one part of the storyline. Try to identify the nature of the plane figure that builds the Marionette Tangram in Bulusan "(the conditional answer is by the characteristics of the plane).

10. Students' answers related to the characteristics of the plane figures are corrected and matched with the following Table 3 .

Table 3. The Plane Characteristics

\begin{tabular}{|c|c|l|}
\hline No & $\begin{array}{c}\text { Plane (Two } \\
\text { Dimensional Figure) }\end{array}$ & Characteristics \\
\hline 1 & Square & $\begin{array}{l}\text { It has four equal lengths and four } \\
\text { equal angles }\left(90^{\circ}\right)\end{array}$ \\
\hline 2 & Rectangle & $\begin{array}{l}\text { It has two pairs of sides of equal } \\
\text { length and four right angles }\end{array}$ \\
\hline 3 & Triangle & $\begin{array}{l}\text { It has three sides, a base and height } \\
\text { and three acute angles }\end{array}$ \\
\hline 5 & Rhombus & $\begin{array}{l}\text { It has four sides, two sides facing } \\
\text { the same length, and two different } \\
\text { sizes of diagonals }\end{array}$ \\
\hline 6 & Parallelogram & $\begin{array}{l}\text { It has four sides, two sides facing } \\
\text { the same length, two different sizes } \\
\text { of diagonals, and two kinds of base } \\
\text { and height sizes }\end{array}$ \\
\hline & Trapezoid & $\begin{array}{l}\text { It has four sides, a pair of parallel } \\
\text { sides, two kinds of base size and } \\
\text { height, the height line is a line that } \\
\text { is perpendicular to the base }\end{array}$ \\
\hline
\end{tabular}

\subsection{Develop Phase}

The results of the development phase are expert validation for the media and the results of the students' questionnaires. There are five content validators and two media validators who asses the media. Table $4 \mathrm{a}$ and Table $4 \mathrm{~b}$ present the results of the expert validation. Table $4 \mathrm{c}$ shows the media assessments from practitioners and users, and table $4 \mathrm{~d}$ presents students' questionnaire results.

Table $4 \mathrm{a}$ and $4 \mathrm{~b}$ show that the development of Marionette Tangram is in the strongly valid criteria. Based on this results, it can be concluded that the media is feasible to use in learning. The scope of the materials and content accuracy become one of the important things in media development. Instructional content is one of the 
factors in learning [18].

Table $4 \mathrm{c}$ and $4 \mathrm{~d}$ show that the application of the media is in strongly valid and valid criteria. Teachers and students declare that the media increases their motivation and curiosity. Moreover, many research show that media can increase student motivation in learning [19].

Table 4a. Content Expert Results

\begin{tabular}{|c|c|c|c|}
\hline No & Indicators & Percentage & Criteria \\
\hline \multirow[t]{3}{*}{1} & Content Completeness & & \\
\hline & Scope of Competencies & $96 \%$ & Strongly valid \\
\hline & Scope of Indicators & $97 \%$ & Strongly valid \\
\hline \multirow[t]{4}{*}{2} & Content Accuracy & & \\
\hline & Theme Suitability & $98 \%$ & Strongly valid \\
\hline & $\begin{array}{l}\text { Mathematics Content } \\
\text { Suitability }\end{array}$ & $97 \%$ & Strongly valid \\
\hline & $\begin{array}{c}\text { History Content } \\
\text { Suitability }\end{array}$ & $98 \%$ & Strongly valid \\
\hline
\end{tabular}

Table 4b. Media Expert Results

\begin{tabular}{|c|c|c|c|}
\hline No & Indicators & Percentage & Criteria \\
\hline 1 & Design and Size & $92 \%$ & Strongly valid \\
\hline 2 & Configuration & $94 \%$ & Strongly valid \\
\hline 3 & Materials and Color & $90 \%$ & Strongly valid \\
\hline 4 & Media Utilization & $98 \%$ & Strongly valid \\
\hline 5 & Packaging & $90 \%$ & Strongly valid \\
\hline
\end{tabular}

Table 4c. Teacher/Practitioner Results

\begin{tabular}{|c|c|c|c|}
\hline No & Indicators & Percentage & Criteria \\
\hline 1 & $\begin{array}{c}\text { Instruction for use in } \\
\text { learning process }\end{array}$ & $90 \%$ & Strongly valid \\
\hline 2 & Easiness of use & $80 \%$ & Valid \\
\hline 3 & $\begin{array}{c}\text { Material content covers } \\
\text { competencies }\end{array}$ & $90 \%$ & Strongly valid \\
\hline 4 & Content accuracy & $92 \%$ & Strongly valid \\
\hline 5 & $\begin{array}{c}\text { Motivate the students to } \\
\text { construct their knowledge }\end{array}$ & $90 \%$ & Strongly valid \\
\hline 6 & Generate students' interest & $95 \%$ & Strongly valid \\
\hline
\end{tabular}

Table 4d. Students Questionnaire Results

\begin{tabular}{|c|c|c|c|}
\hline No & Indicators & Percentage & Criteria \\
\hline 1 & $\begin{array}{c}\text { Instruction for use is easy } \\
\text { to understand }\end{array}$ & $85 \%$ & Strongly valid \\
\hline 2 & Easiness of use & $81 \%$ & Strongly valid \\
\hline 3 & $\begin{array}{c}\text { Media increases } \\
\text { motivation }\end{array}$ & $98 \%$ & Strongly valid \\
\hline 4 & $\begin{array}{c}\text { Media makes the students } \\
\text { happy and interested }\end{array}$ & $95 \%$ & Strongly valid \\
\hline 5 & $\begin{array}{c}\text { Media encourages } \\
\text { curiosity }\end{array}$ & $80 \%$ & Valid \\
\hline
\end{tabular}

\subsection{Disseminate Phase}

The dissemination phase is the phase of disseminating information about the Marionette Tangram media. This dissemination was carried out in Kudus, Central Java,
Indonesia. Moreover, the media copyright has been registered with the copyright registration number 000123371.
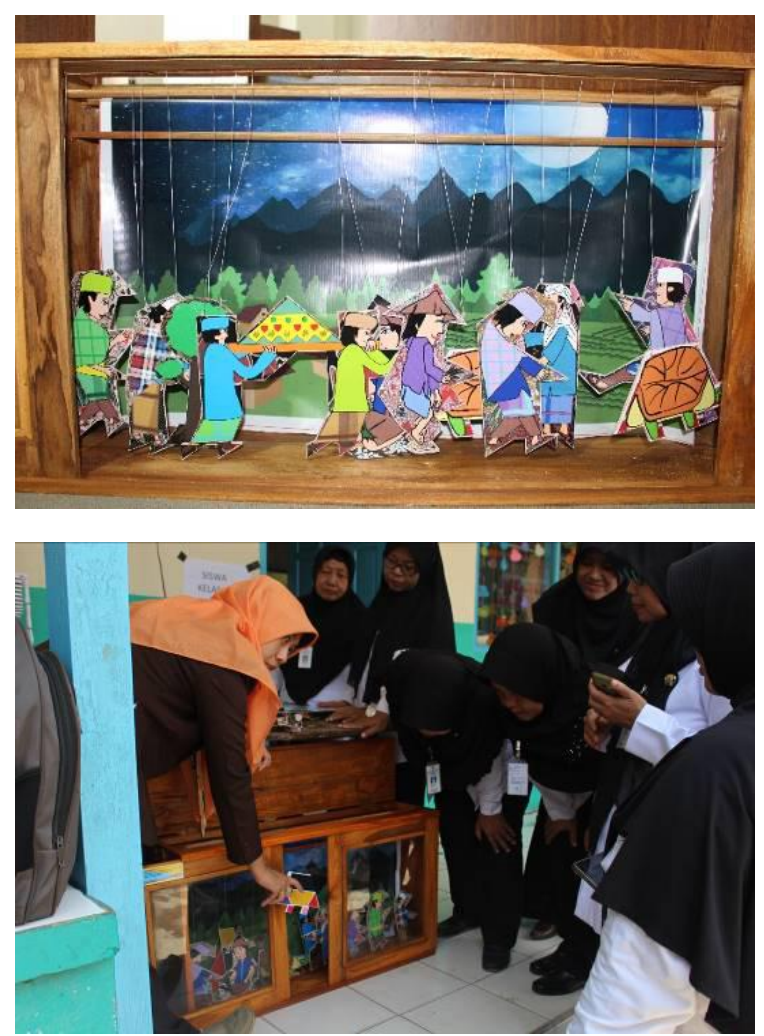

Figure 3. The dissemination of Marionette Tangram Media

\section{Conclusions}

Marionette Tangram as an educational teaching media was considered valid and visible to use in the thematic learning process. The media can be used to teach geometry especially in the topic of plane characteristics. There are six planes in Marionette Tangram. The media can also be used to teach social sciences related to history and character values.

\section{Acknowledgments}

We are very grateful to the Ministry of Research and Technology and Higher Education (Kemenristekdikti) of the Republic of Indonesia for the financial support in the form of research grants.

\section{REFERENCES}

[1] Y. J. John. A" New" Thematic, Integrated Curriculum for Primary Schools of Trinidad and Tobago: A Paradigm Shift. International journal of higher education, Vol. 4, 
No.3, 172-187. 2015.

[2] C.R. Prihantoro. The perspective of curriculum in Indonesia on environmental education. International Journal of Research Studies in Education, Vol.4, No.1, 77-83. 2015.

[3] H. Retnawati, et al. Teachers' difficulties in implementing thematic teaching and learning in elementary schools. The New Educational Review, Vol.48, 201-212. 2017.

[4] E. Surya, E. Syahputra. Improving High-Level Thinking Skills by Development of Learning PBL Approach on the Learning Mathematics for Senior High School Students. International Education Studies, 10.8: 12-20. 2017.

[5] E. Zuliana, F. Setyawan, \& A. Veloo. Helping students mathematical construction on square and rectangle's area by using Sarong motive chess. In Journal of Physics: Conference Series IOP Publishing Vol.943, No.1, 012058. 2017.

[6] E. Zuliana, E. Retnowati, \& D.B. Widjajanti. How should elementary school students construct their knowledge in mathematics based on Bruner's theory?. In Journal of Physics: Conference Series IOP Publishing. Vol.1318, No.1, 01. 2019.

[7] M.A. Ramdhani, H. Muhammadiyah. The Criteria of Learning Media Selection for Character Education in Higher Education. Proceeding International Conference of Islamic Education: Reforms, Prospects and Challenges Faculty of Tarbiyah and Teaching Training, Maulana Malik Ibrahim State Islamic University, Malang. 2015.

[8] E. Rugut, \& N. M. Lazarus. Utilisation of Educational Media in Teaching and Learning of History and Government in Selected Secondary Schools in Kenya. IOSR Journal Of Humanities And Social Science (IOSRJHSS), Vol. 21 No. 9. 2. 2016.

[9] P. Buckley, \& E. Doyle. Gamification and student motivation. Interactive learning environments, Vol.24, No.6, 1162-1175. 2016.

[10] Thiagarajan, Semmel \& Semmel. Instructional Development for Training Teachers of Exceptional Children: A Sourcebook. Washington DC: National Center for Improvement of Educational Systems (DHEW/OE). 1974.

[11] A. Joshi, S. Kale, S. Chandel, \& D. K. Pal. Likert scale: Explored and explained. British Journal of Applied Science \& Technology, Vol. 7, No.4, 396. 2015

[12] S. E. Harpe. How to analyze Likert and other rating scale data. Currents in Pharmacy Teaching and Learning, Vol. 7, No.6, 836-850. 2015.

[13] R. N. Blasiman, J. Dunlosky, \& K. A. Rawson. The what, how much, and when of study strategies: Comparing intended versus actual study behaviour. Memory, Vol. 25, No. 6, 784-792. 2017.

[14] T. Sabri. Value Based Thematics Learning. Journal Of Education, Teaching and Learning. Vol. 2, No. 2, 192-196. 2017.

[15] E. Karahan, E, S. C. Bilici, \& A. Ünal. Integration of media design processes in science, technology, engineering, and mathematics (STEM) education. Eurasian Journal of Educational Research, Vol. 15, No. 60, 221-240. 2015
[16] Y. Kim, \& L. Jehe. Marionette show using quadrotors. Proceedings of the ACM SIGGRAPH/Eurographics Symposium on Computer Animation. ACM, 2017.

[17] T. Trimurtini, E. F. Sari, \& F. Ahmadi. Primary School Teachers' Capability in Developing Learning Media Basedon Tangram Interactive Game. In 3rd International Conference on Education, Sports, Arts and Management Engineering (ICESAME). Atlantis Press. 2018.

[18] A. Kristanto. The Development of Instructional Materials E-Learning Based on Blended Learning." International Education Studies Vol. 10. No. 7. 10-17. 2017.

[19] A. Dorit. College students' academic motivation, media engagement and fear of missing out. Computers in Human Behavior Vol. 49 111-119. 2015. 